\title{
Makalah \\ Analisis Transaksional Dalam Komunikasi Organisasi
}

Diajukan untuk memenuhi tugas mata kuliah Komunikasi Organisasi

Dosen Pengampu :

Ana Ratnasari, M.Pd

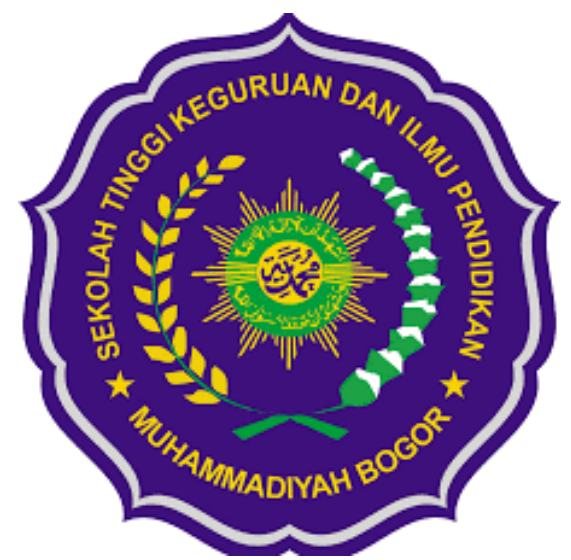

Disusun Oleh :

$\begin{array}{ll}\text { Finka Julfitiah Fadillah } & \text { 0142S1A018003 } \\ \text { Dadang Darmawan } & \text { 0142S1A018047 } \\ \text { Frisdila } & \text { 0142S1A018032 } \\ \text { Yantin Jayanti } & \text { 0142S1A080 }\end{array}$

PROGRAM STUDI ADMINISTRASI PENDIDIKAN STKIP MUHAMMADIYAH BOGOR

Jl.Raya Lewiliang No.106 Bogor 16640 Telepon : (0251) 8644743,Faks : (0251) 8642847

Email : stkipm_bogor@yahoo.com 


\section{KATA PENGANTAR}

Puji syukur kita panjatkan kehadirat Allah SWT atas limpahan rahmat, taufik hidayahnya serta nikmat sehat sehingga penyusunan makalah " Analisis Transaksional dalam komunikasi Organisasi " guna memenuhi tugas sesuai dengan yang di harapkan. Kami mengucapkan terimakasih kepada semua pihak yang telah membantu sehingga makalah ini dapat diselesaikan tepat pada waktunya.

Semoga makalah ini dapat memberikan manfaat dan berguna bagi khalayak umum, dan tidak lupa kami memohon maaf apabila dalam penyususnan makalah ini terdapat kesalahan baik dalam kosa kata ataupun isi dari keseluruhan makalah ini. Kami sebagai penulis sadar bahwa makalah ini masih jauh dari kata sempurna.

Bogor, Desember 2019

Penyusun 


\section{DAFTAR ISI}

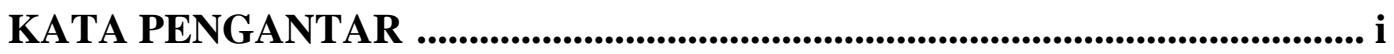

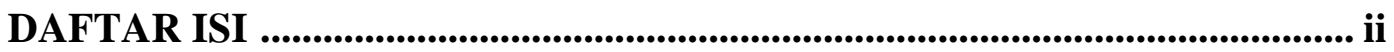

BAB I PENDAHULUAN ................................................................................. 1

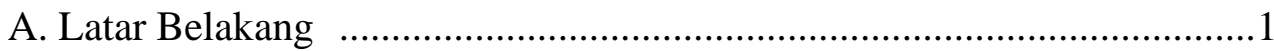

B. Rumusan Masalah ......................................................................... 1

BAB II PEMBAHASAN ....................................................................................2

A. Pengertian Analisis Transaksional ...................................................

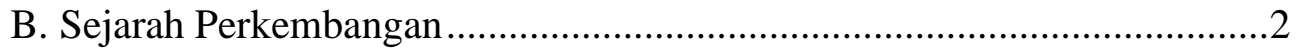

C. Perkembangan Prilaku .............................................................................

D. Jenis Transaksi Antarpribadi................................................................

E. Kelebihan dan Kelemahan dari Analisis Transaksional ..........................4

BAB III PENUTUP ...............................................................................................6

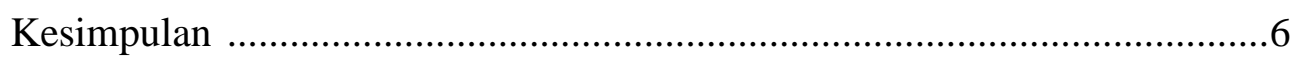

DAFTAR PUSTAKA 


\section{BAB I \\ PENDAHULUAN}

\section{A. Latar Belakang}

Analisis Transaksional adalah salah satu pendekatan psychottherapy yang menekankan pada hubungan interaksional. Analisis transaksional dapat dipergunakan untuk terapi individual, tetapi terutama untuk pendekkatan kelompok. Pendekatan ini menekankan pada aspek perjanjian dan keputusan. Melalui perjanjian ini tujuan dan arah proses terapi dikembangkan sendiri oleh klien, juga dalam proses terapi ini menekankan pentingnya keputusan-keputusan yang diambil oleh klien.

Analisis Transaksional ini dikembangkan oleh Eric Berne tahun 1960. Dalam mengembangkan pendekatan ini Eric Berne menggunakan berbagai bentuk permainan antara orangtua, orang dewasa dan anak.

\section{B. Rumusan Masalah}

1. Apa Pengerian Analisis Transaksional ?

2. Bagaimana sejarah perkembangannya ?

3. Bagaimana dengan perkembangan prilaku?

4. Ada berapa jenis transaksi dalam antarpribadi ?

5. Apa kelebihan dan kelemahan dari Analisis Transaksional ? 


\section{BAB II \\ PEMBAHASAN}

\section{A. Pengertian Analisis Transaksional}

Analisis Transaksional (AT) adalah salah satu pendekatan Psychotherapy yang menekankan pada hubungan interaksional. Transaksional maksudnya ialah hubungan komunikasi antara seseorang dengan orang lain. Adapun hal yang dianalisis yaitu meliputi bagaimana bentuk cara dan isi dari komunikasi mereka. Dari hasil analisis dapat ditarik kesimpulan apakah transaksi yang terjadi berlangsung secara tepat, benar dan wajar. Bentuk, cara dan isi komunikasi dapat menggambarkan apakah seseorang tersebut sedang mengalami masalah atau tidak.

Analisis transaksional terdiri dari dua kata, analisis berarti pengujian secara detail agar lebih memahami atau agar dapat menarik kesimpulan dari bahasa pengujian tersebut, sedangkan transaksional atau transaksi adalah unit pokok dari sebuah hubungan sosial. Dengan demikian, analisis transaksional adalah metode yang digunakan untuk mempelajari interaksi antar individu dan pengaruh yang bersifat timbal balik yang merupakan gambaran kepribadian seseorang.

\section{B. Sejarah Perkembangan}

Teori analisis transaksional merupakan karya besar Eric Berne (1964), yang ditulisnya dalam buku Games People Play. Berne adalah seorang ahli ilmu jiwa terkenal dari kelompok Humanisme. Teori analisis transaksional merupakan teori terapi yang sangat populer dan digunakan dalam konsultasi pada hampir semua bidang ilmu-ilmu perilaku. Teori analisis transaksional telah menjadi salah satu teori komunikasi antar pribadi yang mendasar.

Kata transaksi selalu mengacu pada proses pertukaran dalam suatu hubungan. Dalam komunikasi antarpribadi pun dikenal transaksi. Yang dipertukarkan adalah pesan-pesan baik verbal maupun nonverbal. Analisis transaksional sebenarnya bertujuan untuk mengkaji secara mendalam proses 
transaksi (siapa-siapa yang terlibat di dalamnya dan pesan apa yang dipertukarkan).

\section{Perkembangan Perilaku}

Struktur kepribadian Ketika Berne menghadapi klien, ia menemukan bahwa kliennya kadang-kadang berfikir, berperasaan dan berperilaku seperti anakanak, tapi di lain kesempatan terlihat seperti orang tua atau orang dewasa. Berdasarkan pengalamanya dengan klien itu, Berne berkesimpulan bahwa manusia memiliki berbagai bentuk kondisi ego, atau disebutnya dengan ego states yaitu unsur-unsur kepribadian yang terstruktur dan itu merupakan satu kesatuan yang utuh. Adapun struktur kepribadian itu terdiri dari 3 status ego yaitu ; ego orang tua, ego dewasa dan ego anak.

1. Status Ego orang tua. (ego state parent) Yaitu bagian dari kepribadian yg menunjukkan sifat-sifat orang tua, berisi perintah (harus \& semestinya). Jika individu merasa dan bertingkah laku sebagaimana orang tuanya dahulu, maka dapat dikatakan bahwa individu tersebut dalam status ego orang tua. Status ego orang tua merupakan suatu kumpulan perasaan, sikap, pola-pola tingkah laku yang mirip dengan bagaimana orang tua individu merasa dan bertingkah laku terhadap dirinya.

2. Status Ego dewasa(Ego state adult) Yaitu bagian dari kepribadian yg objektif, stabil, tidak emosional, rasional, logis, tidak menghakimi, berkerja dengan fakta dan kenyataan-kenyataan, selalu berusaha untuk menggunakan informasi yang tersedia untuk menghasilkan pemecahan yang terbaik dalam pemecahan berbagai masalah. Dalam status orang dewasa selalu akan berisi hal-hal yang produktif, objektif, tegas, dan efektif dan bertanggung jawab dalam menghadapi kehidupan. Jika individu bertingkah laku sesuai dengan yang telah disebutkan tadi, maka individu tersebut dikatakan dalam status ego dewasa..

3. Status ego anak (ego state child) Yaitu bagian dari kepribadian yang menunjukkan ketidakstabilan, reaktif, humor, kreatif, serta inisiatif,masih dalam perkembangan, berubah-ubah, ingin tahu dan sebaginya. Status ego anak berisi perasaan, tingkah laku dan bagaimana berpikir ketika masih kanak-kanak dan 
berkembang bersama dengan pengalaman semasa kanak-kanak. Sikap dasar manusia. Sehubungan dengan penilaian seseorang terhadap dirinya (I) dan orang lain (you), Berkaitan dengan konsep -konsep sekenario kehidupan, pesan - pesan dan perintah - printah orang tua, dan putusan - putusan dini itu, adalah konsep dalam AT tentang empat posisi dasar dalam hidup:

1. Saya Ok - kamu OK

2. Saya OK - kamu Tidak OK

3. Saya Tidak OK - kamu OK

4. Saya Tidak OK - Kamu Tidak OK.

Masing - masing posisi itu berlandaskan putusan - putusan yang dibuat orang sebagai hasil dari pengalaman dini di masa kanak - kanak. Jika seseoran telah membuat suatu putusan, maka dia pada umunya akan bertahan pada putusan nya kecuali jaka ada campur tangan ( terapi atau kejadian tertentu )yang mengubahnya. Posisi yang sehat adalah posisi dengan perasaan sebagai pemenang atau posisi Saya OK - Kamu OK.

\section{Tiga Jenis Transaksi Antar Pribadi}

1. Transaksi Komplementer

Dalam Transaksi ini terjadi kesamaan makna terhadap pesan. Pesan yang satu dilengkapi pesan yang lain meskipun dalam jenis ego yang berbeda.

2. Transaksi Silang

Dalam transaksi ini pesan yang dikirimkan oleh komunikator tidak mendapat respon yang sewajarnya dari komunikan.

3. Transaksi Tersembunyi

Transaksi ini terjadi bila campuran beberapa sikap di antara komunikator dan komunikam sehingga salah satu sikap menyembunyikan sikap yang lainnya.

\section{E. Kelebihan dan Kelemahan Analisis Transaksional}

1. Kelebihan dari Analisis Transaksional

a. Punya pandangan optimis dan realistis tentang manusia. 
b. Penekanan waktu di sisni dan sekarang ( here an now ).

c. Mudah diobservasi.

d. Meningkatkan keterampilan berkomunikasi.

2. Kelemahan dari Analisis Transaksional

a. Kurang efesien terhadap kontrak treatment karena banyak klien yang beranggapan jelek terhadap dirinya dan tidak realistis sehingga sulit tercapai kontrak karena klien tidak dapat mengungkapkan tujuan apa yang ia inginkan.

b. Subyektif dalam menafsirkan status ego. 


\section{BAB III \\ PENUTUP}

\section{Kesimpulan}

Pada dasarnya kata transaksi selalu mengacu pada proses pertukaran dalam suatu hubungan. Dalam komunikasi antarpribadi pun dikenal transaksi. Yang dipertukarkan adalah pesan-pesan baik verbal maupun nonverbal. Analisis transaksional sebenarnya bertujuan untuk mengkaji secara mendalam proses transaksi ( siapa-siapa yang terlibat di dalamnya dan pesan apa yang dipertukarkan). Setiap tindakan dengan orang lain merupakan proses timbal balik dan peraturan memulai, merespon, dan memberi umpan balik.

Berne mengamati bahwa kehidupan sehari-hari banyak ditentukan oleh bagaimana ketiga status ego ( anak, dewasa, dan orang tua )saling berinteraksi dan hubungan transaksional antara ketiga status ego itu dapat mendorong pertumbuhan diri seseorang tetapi juga dapat merupakan sumber-sumber gangguan psikologis jika ketiga ego tersebut tidak dimanfaatkan dengan baik karena hanya menerapkan satu jenis status ego saja. 


\section{DAFTAR PUSTAKA}

https://wsmulyana.wordpress.com

https://www.slideshare.net

http://kandidatkonselor.blogspot.com/2013/01/teori-dan-pendekatan-konselinganalisis.html

http://akhmad-sugianto.blogspot.com/2014/03/teori-pendekatan-analisis$\underline{\text { transaksional.html }}$

https://lutfatulkhoeriyahblog.wordpress.com/2014/05/08/makalah-analisis$\underline{\text { transaksional/ }}$

https://diazprabowopm.wordpress.com/2014/04/07/teori-analisis-transaksional-berne/ http://olcounseling.weebly.com/analisis-transaksional.html

https://lutfatulkhoeriyahblog.wordpress.com/2014/05/08/makalah-analisistransaksional/ 